\author{
VALERIU LEAHU \\ LIA BATRÂNA \\ AD́RIAN BÁTRÂNA
}

Cercetăr de suprafață efectuate in primăvara anului 1986 pe valea Buzăului. intre Nehoiaș și Pătârlagele au identificat pe teritoriul satului Mlăjet. comuna Neholu. Județul Buzău, o stațiune arhëologică cu resturi de locuire dín perioada hallstattiană târzie și de la începutul celei de a doua epoci a fierului. Statilunea se află pe terasa stângă (înaltă) a Buzăului, pe locul numit "Lunca Topilei". siluai in apropierea haltei CFR Șețu și in imediata vecinătate a podului care traversează rául și care, apoi. este urmat de drumul ce duce in satul Mlăjet. $O$ localizare a punctului arheologic poate fi stabilită și prin raportare la șoseaua BıŁzăı - Brașov, stațiunea aflându-se pe partea dreaptă a căli rutiere, în dreptul KIII. 91.900.

Potrivii unor observații, in acest sector, podul teraset, inalt de 5 - $9 \mathrm{~m}$, pare sá li fost in vechime mal întins și mai inalt. Micșorarea suprafeței sale și denivelărlle existente. pe alocurı accentuate, s-au datorat - ulterlor, de-a lungul veacurilor - expansiunii albiei Buzăului, desprinderilor și surpărilor din peretele de stancă ce mărginește terasa spre est-nord-est, deplasărllor versantului, dar și unor amenajări moderne: podul peste râu și drumul care. pe malul stâng al apei. duce in satuıl Mlăjet.

Săpăturile efectuate' in anil 1986 ș1 1987 au afectat din intinderea terasei o suprafatã de aproximativ $1000 \mathrm{~m}^{2}$.

Stratierafia observată a fost următoarea:

Sub solul vegetal, cu grosime intre $0,15-0,50 \mathrm{~m}$, se află o depunere de pàmânt castaniu, a cărel grosime variază, de asemenea, intre $0.20-0.30 \mathrm{~m}$ : succede un strat castaniu - cenușiu, gros între $0,20-0,60 \mathrm{~m}$, continând, mai ales către baza sa. rare restur ceramice din prima epocă a flerului; pe o intindere de circa $250 \mathrm{~m}^{2}$ din aria investigată a fost identificată, în zona medıană a acestui strat, o mare platfonnă de pietre, pe a cărei suprafată au putut $\mathbf{f}$ surprinse fragmente de vase de la inceputul celei de a doua epoci a fierului; de la limita inferioară a 
stratului castaniu - cenușiu se adânceau gropile de bordel și menajere, cu resturi de locuire propril Hallstatt-ului târzıu; dedesubt s-a constatat un strat nisıposargilos, lar sub acesta, o depụnere de pletriș zăcând pe stânca-suport a terasel (unele elemente de stratigrafie sunt indicate pé profilele reprezentate în Pl. I și II ).

Deși bordeiele și gropile menajere hallstattiene au avut toate aceeași limită de pornire în jos; baza stratului castaniu-cenușlu. materialele ceramice descoperite în umplutura lor s-au diferențiat tipologic și cronologic. Nediferențierea stratigrafică a complexelor de locuire, în pofida multelor și repetatelor observațil, poate fi pusă în legătură, eventual, cu unele procese naturale proprí zonei, respectiv alunecări de teren și, mal ales, spălări ale unor straturi.

complerele de locuire descoperite sunt douá locuințe de tip bordel, o vatră deschisă și zece gropi menajere.

Bordelul_nr 1 (Pl. I). Groapa acestuia, orientată N- S. a avut conturul rectangular cu colțurile rotunjite. Lungimea și lățimea, măsurate la gură, au fost: 6 m și respectiv $5,40 \mathrm{~m}$. Adâncimea, măsurată în zona centrală, a fost $-0,80 \mathrm{~m}$. Perețil fuseseră orientați uṣor oblic către fund, acesta filind podit cu strat de lut bine bătătorit. Intrarea nu a fost amenajată prin afectarea coñturului locuinței accesul făcăndu-se, probabil, cu ajutorul ụnei scări, al unor butuci de lemn sau ạ unor pletre. Probabil că de la gură in sus groapa să fi fost continuată de pereṭi amenajați din schelet lemnos ușor acoperit cu lut amestecat cu păloase; o mărturie în acest sens ar putea-o constituı resturile, cu mărimi variabılle, de chirpici purtând pe o față amprente de nuiele (Pl. III. 5). Prezența în umplutura gropil a unei cantități relativ mari de cenușă și a unor pietre pare să indice că acoperișul va fi fost amenajat din stuf, păpuriș sau păloase, "fixate" prin greutăți. În interior, pe podea. aproximativ în centru a fost constatată o vatră cvasicirculară, amenajatả dín pietre de râu și de râșniță, ultimele dispuse cu fața în jos. Pe vatră și în preajma sa au fost descoperite o protomă de berbec din ceramică (Pl. VI, 3), fragmente de vase ceramice și oase de animale, întregi și fragmentare, multe puternic arse. "Dispoziția inteționatā a acestor piese in cadrul vetrei - a apreciat Alexandra Bolomey - este indiscutabilă și corespunde, foarte probabıll, unuı ritual efectuat înainte de părăsirea locuinței". La desvelire, in pământul de umplutură a gropii au, fost constatate, împreună cu cele menționate: o râșniță de piatră, întreagă (P1. III, 8), cinci fragmente de pietre mari de rău, cinci frecătoare din platră, cinci fusaiole din lut ars (Pl. III, 1 - 3), un creuzet din platră (Pl. III. 7), un fragment dintr-o lamă de 
cuțit din fier (Pl. III, 6) o cute din piatră, șase bulgări de ocru galben și roșu (vezi PI. III, 4), oase de animale, intregi și fragmentare. fragmente de vase ceramice.

Bordelul_nr_2 (Pl. II). Groapa sa, orientată E - V, a avut contur oval neregulat, cu diametre, măsurate la gură, de $4,20 \times 2.90 \mathrm{~m}$. Adâncimea maximă, măsurată, de asemenea, in centru, a fost de $1,40 \mathrm{~m}$. Pereții cădeau, și aici. ușor oblic, dinspre gură spre fund; acesta păstra o depunere foarte subțire de pământ lutos, neb̆ătătorit, ci tasat prin călcări repetate, din vechime. În colțul nord - estic. intrarea a fost amenajată prin "gârlici" cu forma neregulată, cu două trepte săpate, placate cu pietre de râu. Nu s-au inregistrat indicil cu privire la modul de amenajare a acoperișului. În exterior, apropiată de latura nordică a locuinței se afla o vatră ridicată pe pat de pietre de rău, peste care s-a depus un strat de lut bătătorit, fătuitit; slaba și inegala înroșire și consistență a acestuia sugerează că vatra abia dacă a fost folosită. In pământul de umplutură au fost constatate resturi osteologice animale, in procent simțitor redus comparativ cu frecvența acestora in B. 1.și fragmente ceramice.

Vatra. Portativă, rectangulară, cu gardină inaltă, a fost lucrată din lut amestecat cu păloase, foarte bine ars, și așezată pe un pat din pietre de râu. riguros ordonate. Lungimea: $1,04 \mathrm{~m}$; lățimea: $0,72 \mathrm{~m}$; înălțimea: $0,12 \mathrm{~m}$.

Groplle. Toate fiind in forma fundului de sac, cu diametrele guril varind intre $0,40 \mathrm{~m}$ și $0,68 \mathrm{~m}$ și adâncimile intre $0.37 \mathrm{~m}$ si $0,62 \mathrm{~m}$, au conținut resturi materiale puține (oase de animale și ceramică) numai in stare fragmentară și cu frecvență variabilă.

Oasele de mnimale probează : potrivit determinărlor făcute de Alexandra Bolomey - creșterea și folosirea în așezare a următoarelor specil domestice: bovine (37.5\% din intregul eșantion studiat), rumegătoare mici (11.5\%), porc (7.4\%), cal (6.4\%), și câine $(4,3 \%)$. Ca specii vânate au fost identificate: cerbul (14.9\%), mistrețul $(9,2 \%)$, bourul și zimbrul $(1,8 \%)$, căpriorul (1,6\%); de asemenea, prin câte un fragment, jderul și ursul. Aceeași cercetătoare a stabilit, pe ansamblul materialelor osteologice, procentul de $70 \%$ animale domestice și de $30 \%$ specil sălbatice ${ }^{(3)}$.

Ceramica. Se clasifică. după tehnica de lucru a recipientelor în două mar grupe: A, lucrată cu mâna și $B$, la roată; prima grupă este masiv precumpănitoare. a doua, foartè slab reprezentată. 
Vasele realizate cu mâna se ordoneazà. in functie de pasta din care au fusł lucrate. in douà catégorii.

Al. Grupeazã exemplare poroase. din lut insuflcient frămántai și cu degresanṭi (pleavà. piatră mărunt sfăràmată. cioburi pisale) ce au fosi neglijenl triaṭi și dozați. Arderea, nu de puṭine ori incompletă, a fost in genere oxidaılă. exteriorul pereṭilor pręentānd culoare cărămiże sau roṣcatà. cu nuante variate. uneori virànd către cenuṣiu.

Ca fonne au putut fi partial reconstituite: a) vase de tip sac. (cu pereti crosi. cu funduri intinse. drepte. neprofilate: b) vase cu corp arcuit, cu gail relativ illall. aplecai spre interior: c) castroanele tronconice cu pereți de asemenea groși: (l) vaste cu pantece bombat: e) capace discónidale cu apucátoare.

Decorul acestor recipiente, sărac, avea rol functional: proemintente apucători (semiovale, rectangulare, simple sau cu alveolä) și brauri alveulall' Idispuse sub buză și pe umeri. rareori desfășurate pe corp prin ramificalıii (lesprinse din bandā orizontalà continuă).

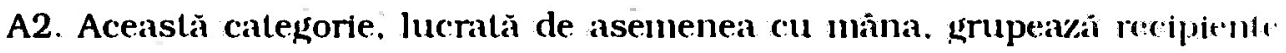
din pastă de bună calitale. lutul fiind mai bine frămantat. iar degresantii. mai lini. fiind dozați in proporṭii reduse. Adeseori exteriorul vaselor a fost acoperii cu slip fin. in repetate cazuri lustruii. Și arderea a fost mai bunà - cel mai adesea oxiclintii. nu de puṭine ori insă și in mediu cu oxigenul redus: suprafeṭele recipientelor apar ast[e] precumpănitor cărănnizii. cu nuanṭe diverse. dar și cenuṣii - castaunii. iariși nlai inchise ori mai deschtse.

Fonnele principale - reconstituite și in acest caz pe baza unor profile fragımentare - sunt unnātoarele: a) vase mari. inalte. cu gură evazală. gà uṣof sırans, cu pansa bombatā, transpuse in mai imlte variante, in functie de graclul de. evazare a gurii, de confonnația buzei, de ingustimea gatului sall de bonbarea pansei (PI. IV. 1. 3. 4. 8): b) vase mari și mijlocii cu corp arcuil convex. cu guma largà. avānd marginea scundà rāsfràntà in exterior, cu proeminente - apucàturi pe. partea superioară (Pl. IV, 2): c) vase mari și mijlocii cu corpul arcuil convex de liı gură spre fund (PI. IV. 5): d) vase. mijlocii sau mat mari. bitronconice (PI. IV. 7) uneori cu ullargínea ușor profiląlă drept (PI. IV, 12): e) vase de típ clopol (PI. IV. 6): f) castroane tronconice (PI. IV, 14) sau cu corpul arcuit convex (PI. IV. 9) cu proeminențe - apucălori pe partea superioară a corpului, unele exemplare. prevāzute cu torți orizontale prinse sub bưà, avảnd fle marginea teșită orizontal și 
profilată (Pl. IV, 10) fie margınea evazată (Pl. IV, 11); g) străchini tronconice cu margine vertıcală, dreaptă (Pl. V, 1 - 5) sau trasă spre Interıor, fle arcult (Pl. V,6, 8 , 11) fle frântă oblic (Pl. V, 7) sau cu marginea înaltă, evazată (Pl. V, 12 - 15), flecare lip avănd variante determınate de gradul de arculre sau de evazare a margınılı sau de conformația buzei; h) cești, unele, mari și mijlocil, filnd de tip căuṣ (PI. VI, 5 - 6) cu toartă din bandă lată, trasă din buză, suprainălțată și uneori prevăzută cu buton, discoidal (Pl. VI, 1, 2, 4) sau zoomorf (Pl. VI, 3), alte exemplare, micl, mal rar mijlocil, de asemenea cu toartă, avānd corpul tronconic (P1. VII, 1 - 2); căni (rare) cu toartă (torți), de dimensiuni, mijlocil și mal mari, cu corpul bombat sau arcuit bitronconic, un fragment atestând și exemplare cu gura înaltă și evazată (PI. VIII. 6).

Pe recipientele lucrate cu mâna din pastă de buna calitate (categoria A2 ) decorul apare foarte rar. Alătuni de proemınențele - apucători al căror rol este și alci funcțional, pot fi menționate doar canelurile. rar întālnite (PI. VIII, 2- 4), tratarea în fațete (benzi fațetate) a exterioruluı unei străchı̀nı (PI. VIII, 1) și în fine, o aplicație plastică în formă de rython pe umărul unuil vas de tıp A2a (Pl. X,2).

Perforațille circulare întālnite izolat pe mal multe fragmente de reciplente (îndeosebi străchıni) din categoria A2 (P1. IX) nu pot fl considerate elemente decorative. Este adevărat că nici nu putem preciza rostul lor ${ }^{4}$. Analogil pentru acestea se întālnesc pe ceramica hallstattiană târzle de la Bârsești - Vrancea, unde insă astfel de găuni circulare sunt dispuse în șir sub buza vasului. Intr-o asemenea dispunere ele au, cum a remarcat Sebastian Morintz, similitudini pe ceramica găsită în mormintele scitıce de pe Niprul mujlociu ${ }^{5}$

Ceramica lucrată la roată (grupa B), din pastă fină, foarte bine frământată, deosebit de compactă, conținând doze minime de degresanți fini și în toate cazurile. foarte bine arsă (cu suprafețele exterioare și Interioare numai de culoare cenușie) a fost descoperită în stare extrem de fragmentată. Din această cauză posıbllitățlle de precizare a unor forme sunt cu deosebıre reduse. Cu suficientă certıtudine se poate menționa numai prezența unor străchinı șı a unor căni cu toartă. Câteva fragmente de vase mari (de funduri șl perețt) ar putea eventual, provenı de la amfore (vezı PI. IX). 
Încadrarea cronologică și culturală a resturilor așezăril de la Mlăjet Buzău se poate obține pe baza analizei comparativ-tipologice a materialelor ceramice. În această privință a fost evident încă din faza cercetărilor în teren, incă din timpul dezvelirii și tratărí complexelor de locuire, că descoperirle din punctul "Lunca: Topile1" au cât se poate de bune analogii in ceramira faciesului cultural hallstattian târziu de tip Ferigile - Bârsești.

Astfel, vasele mari, înalte, cu gura evazată, gât ușor strâns și pansa bombată (tipul A2a, PI. III. 1, 3, 4, 8) pot fi apreciate drept corespondent deplin al "vaselor mari pântecoase" (tipul V in clasificarea lui Alexandru Vulpe) din necropola de la Ferigile ${ }^{6}$. Vasele mari și mijlocii, cu corp arcuit convex, cu gura largă având marginea scundã răsfrântă în exterior și cu gât scurt și larg, cu proeminențe apucători pe partea superioară a corpului (tipul A 2 b. Pl. III 2) de la Mlăjet - Lunca Topilei își au analogia în ceea ce tot Alexandru Vulpe a numit "vasele pântecoase de tip Tigveni ${ }^{7}$. De asemenea, diverse tipuri de vase - borcan, cu deosebire tipurle VI Al, VI A2 și VI D, din clasificarea lui Vulpe ${ }^{8}$. caracteristice pentru ceramica grupului Ferigile - Birsești, au fost și ele descoperite în așezarea pe care o prezentăm (vezi Pl. III. 6, 9, 13). Ceașca tronconică cu toarta supraînălțală prevãzutã cu buton discoidal (tipul II A de la Ferigile) intâlnită in necropola eponimă, dar și la Cepari sau Tigveni - Babe ${ }^{y}$, a apărut și la Mlàjet - Lunca Topilei. in Bl și in stratul de cultură. La fel, au fost constatate aici și ceștile ("ceșcuțele") tronconice cu toartă supraînălțată (Pl. VII, 1 -2) inseriate, la Ferigile, în tipul II B $\mathrm{B}^{10}$. In fine, mai menționăm că tipurile de străchini descoperite de noi, publicate acum (Pl. V) se atașează, aproape toate, unor tipuri determinate la Ferigile - dar prezente și in alte necropole proprii aspectului cultural în discuție -respectiv tipurilor $1 \mathrm{~A}$ cu variantele $\mathrm{A} 2,3$ și 4, I B3 și Dai și $\mathrm{Db}^{11}$.

Unele dintre materialele ceramice de la Mlăjet - Buzău iși aflà similitudinile și in descoperirile de la Bârsești - Vrancea. Semnalăm ca alare. alături cu deja menționatele găuri circulare.de pe vase, indeosebi foarte bunele analogii dintre tipurile de vase - borcan, dintre care unele străchini evazate, dar. mai ales. dintre ceștile tronconice cu toartă suprainălțată ${ }^{12}$.

Puṭinele elemente de decor constatate pe ceramica de la Mlăjet iṣi kăsesc., și ele, analogiile tot in mediul cultural Ferigile - Bârsești, unde sunt bine reprezentate brâurile alveolate, canelurile, fațetarea, elemente in relief aplicate pe exteriorul unor recipiente sau butonii zoomorfi de pe torțile unor cești ${ }^{13}$. 
Raportarea și atașarea ceramicli din așezarea hallstattıană târzie de lâ Milăjet, la aspectul (grupul) cultural Ferigile - Birseștí, trebuie insă să ṭină seama și de ce se dovedeṣte a fl de natură să particularizeze descoperirea prezentată de noi, în cadrul faciesului menționat. Semnalăm, de aceea, că două forme atât de bine reprezentate in ansamblul descoperirılor de tıp Ferıglle - "strachı́na - căzănel" și “ceașca pântecoasă" (tipurile I C și III în clasificarea lụ Alexandru Vulpe ${ }^{14}$ ) lipsesc la Mlăjet (fragmentele de castroane cu torți orizontale prinse sub buză - vezi Pl. IV, 10, 11) neputând fl confundate cu vasele de tip lekane de la Ferigile sau Tigveni. Trebule de asemenea relıefată prezența la Mlăjet a fragmentelor de vase lucrate la roata olarului (Pl. XI), câtă vreme o atare categorie ceramică abia dacă este inregistrată in necropole de típ Ferlgłle cercetate până in prezent (la Bârseștı. categoria în discuție este menționată ${ }^{15}$ ).

Este foarte probabil că asemenea deosebir au o motivație mal complexă. Nu trebuie astfel uitat nici un moment, că in incercarea de a omologa cultural și cronologic descoperirea de la Mlăjet - Lunca Topllei - intemeindu-ne pe ceea ce a apărut drept caracteristic în ceramică - am fost în situțla de a compara mereu materiale aflate intr-o așezare, cu altele, extrase din necropole, selectate pentru a f depuse acolo ca inventar funerar ${ }^{16}$. Se cere de asemenea reținută ímprejurarea că materialele supuse comparăril sunt, în bună măsură, distanțate teritorial. Grupul necropolelor de tip Ferigile, surprins până acum în arille județelor Vîlcea și Argeṣ se silueayă astfel depărtat cu aproximativ 150 km (în linie dreaptă) de așezarea de la Mlăjet, care, în felul acesta, pare a se atașa geografic și cultural, mal degrabă sectorului Bârsești. Asemenea sıtuații au influențat într- adevăr și până la ce limite - fizionomia diferitelor manifestări de cultură materială și spirituală străvechı ? Ràspunsul este cu atât mal dificil de obținut in cazul analizat, cu cât, se știe, descoperirile de tip Bârsești sunt încă puține, oarecum Izolate și oricum, departe de a fi suficiente unor examinări multiple,complexe și concludente. În fine. este firesc sã admịtem cã anume deosebiri intre materialele descoperite la Mlăjet și ceramica din necropolele de típ Ferigile - Bârsești cunoscută până acum se datoresc și unor diferențe de ordin cronologic.

Neîndoielnic, absența aproape totală la Mlăjet, a decorului canelat sau în relief, întâlnit la Ferigile - cu înfățișări atât de caracteristice - pe străchinile evazate, pe ceștile de tip IIA sau pe cănile tip IV; ori dimpotrivă, prezența în așezarea de la lunca Topilei a vaselọ pântecoase de típ Tigveni - asemene a elemente sugerează că 
descoperirea de pe malul Buzăului atestă un facies mai târziu din evoluṭia grupului Ferigile - Bârsești.

Pentru a preciza, pe cât este cu putință. poziția cronologică a acestei locuîri hallstsțtienẹe, apare însă necesară, mai intâl, detalierea unui fapt deja menționat: prin câteva particularități de amenajare a adăposturilor. dar. mai ales. prin ceramică, cele două complexe de locuire ${ }^{17}$ de la Mlăjet - Lunca Topilei și - au arătat, unul față de celălalt, nu numai trăsăturile de unitate, dar și unele deosebiri.

Astfel. in privința tipului de locuință se cere remarcat că Bl. cu suprafața locuibilạa mai mare, cu forma sa (rectangulară având colțurile rotunjite), cu vatra din interior, podit fiind cu strat de lutulală, așternut și bătătorit, și fără a avea intrarea amenajatã prin afectarea conturului locuinței, s-a diferențiat de B2, cu suprafața locuibilă mai redusă, cu forma sa oval - neregulată, fără podea de lut bătătorit, cu vatră în exterior, dar cu intrare de tip gârlici cu trepte pietruite.

In privința inventarului ceramic trebuie notate următoarele: in $B 1$ se regăsesc cele mai multe dintre tipurile de străchini întâlnite în necropolele de tip Ferigile, Iar alături de acestea, ceștlle cu toarta supraînălțată prevăzutã cu buton discoidal, ceșcuțele tronconice cu toartă, vasele pântecoase. cu excepția însă a acelora de tip Tigveni. De asemenea în $\mathrm{Bl}$ (și numai aicil) au fost constatate fragmentele ceramice cu decor canelat descoperite în așezare. In schimb, în B2 lipsesc ceștile căuṣ cu buton discoidal pe toartă. străchinile evazate, ceștile tronconice, decorul cu caneluri. Vasele pintecoase de tipul V - Ferigile au acum o alură mai greoale, fiind mai scunde dar mai extinse în diametru (atât la gură cât și la pansă). Neexistente în B1, apar în B2: vase pântecoase (fragmente) de tip Tigveni (Pl. IV, 2), profile de străchini neîntâlnite deocamdată in necropolele grupului Ferigile - Bărsești (Pl. V, 4, 9), torți de căni având pe spinare puternic reliefate nervuri longitudinale, paralele (Pl. $\mathrm{X}, 1$, 4), vase clopot cu brâuri alveolate ramificate pe corp (desprinse din proeminențe - apucători, Pl. X, 5).

Datele consemnate duc la concluzia cá cele două locuințe târzii hallststtiene de la Mlăjet - Lunca Topilei nu sunt contemporane; bordeiul nr. 2 este mai târziu decât primul, in ceramica sa regăsindu-se șl elemente ce uneori par chiar a fi depășit evoluția grupului cultural Ferigile - Bârsești (așa cum este acesta definit pànă în prezent).

Cum ar putea fi incadrate cronologic, mai strâns, aceste două locuințe ? 
Pentru ceramica descoperitā în bordelul nr. 1 , cele mal multe și mai bune analogii pot fi regăsite printre materialele proprí fazei numite Ferigile III. Intradevăr, fonnele reciplentelor din această locuință, reconstitulte, iși află, fiecare, corespondent îndeosebi în vasele - borcan, castroanele, străchınılle, vasele pántecoase, ceștile - căuṣ sau ceșcuțele tronconice descoperite in necropola eponimă, în tumulî $9,40,42,77$, etc. ${ }^{18}$, și mal mult, mal apropiat încă în ceramica tumulilor 2, 5, 9, 11, 13 și 14 de la Tigveni r.Babe ${ }^{19}$ sau în inventarul primului tuunul de la Tițeștı - Argeș ${ }^{20}$. Totodată, avem în vedere prezența printre resturile ceramice din Bl a unul fragment din partea superloară a unei căni (porțiunea de gură cu segment de toartă prinsă pe buză) lucrată la roată ( $\mathrm{Pl}$. XI, 3). típ de recıplent ce iși găsește deplina analogie în necropola de la Slobozia ${ }^{21}$, datată în Intervalul de timp 450-350 î. Chr. Pe baza unor asemenea asocier comparativ tipologice, credem că bordelul nr. 1 de la Mlăjet - kunca Topilel poate fi datat în a doua jumătate a secoluluı V - inceputul secolului IV î. Chr.

In cel de al doilea bordei, însã unele materiale iși aflả analogil în descoperin mai târziı. Pentru exemplificare, menționăm, întâi, fragmentele de vase "clopot" cu decor de brâur alveolate ramificate pe corpli desprinse dintr-un brâu orzzontal întrerupt de proeminențele - apucători. Se știe cá - necunoscut până acum in inventarul ceramic propriu grupului cultural Fengile - Bârsești - acest tip de vas, chlar dacă apare în secolul V. i. Chr. ${ }^{22}$, este cu deosebire specific culturil getice din secolele IV și III i. Chr ${ }^{23}$. La fel, străchinile tronconice - cu marginea dreaptă sau puțin trasă spre interior, cu buza profilată în exterior sau nu, dar intotdeauna teșitã oblic - și ele iși au corespondent in exemplare descopertte în necropola getică de la Zimnicea și datate acolo în secolele IV - III î. Chr. ${ }^{24}$. În fine. un fragment din partea superioară a unei câni (PI. VIII, 6) arată că aparține unui tip ce se întâlnește deasemenea în secolele IV și III 1. Chr. ${ }^{25}$. Pe astfel de date sprijınindu-ne, opinăm că bordelul nr. 2 poate fi datat în cursul celei de a doua jumătățı a secoluluıı IV î. Chr., înclinând, mai curând, către finele acestuı veac.

O asemenea încadrare cronologịcă pune însă problema următoare:

Tinând seama de data (secolul V, poate și începutul secolulự IV î. Chr.) stabıllită de Alexandru Vulpe pentru cele mal târzii manifestăr de tı́p Ferigile Bârsești. Identificate pâna acum²6; dar luând în considerare și opintıle lui Emıl Moscalu, dupã care o serie de descoperiri arheologice probează, "începutul aspectului Canlia în Muntenia, în a doua jumătate a secolulư VI și prima jumătate 
a secolului V î. e. n." ${ }^{27}$, astfel încât "între 450 - 400 aspectul Canlla era pe deplín format" ${ }^{28}$, intr-o atare situație ce ar putea să marcheze sub raport cultural arheologic cea de a doua locuință hallstattiană târzie de la Mlăjet - Buzău ? Constituie ea ipostaza unui nou orizont târzłu propriu grupului cultural Ferigile Bârsești, ce succede celui atestat prin descoperirile de la Cepari - Bisericà șı Tigvenı - Babe (tumuliı 2, 5, 9 - parțial, 11, 13, ș1 14) ? Sau, dimpotrivă, bordelul nr. 2 dın Lunca Topılei atestă un alt aspect cultural ? - filnd posıbıll ca acesta să fie aspectul Canlia, intr-o infáțișare timpurie a sa. Problema formulată este Interesantă, Incitantă chlar, ștıut filınd că până in prezent nu este deloc clar ce anume urmează -. ca populație șı cclvilizație autohtonă - in aria grupului cultural Ferigile - Bârsești după incheterea evoluțiel sale. Emıll Moscalu a opınat cã "continuitatea aspectului Ferigile in aria sa, in sec. IV - III $\hat{i}$. e. $n$. este aproape sıgurā"2y, nefiınd astfel exclus ca el "să dăınule până la formarea culturiı Sannizegetusa"30 . Dar același cercetător a demonstrat cả între aspectele Ferigılle Bârseștı șı Canlia au existat o serie de elemente (tıpuri ceramice, cu variante) comune $^{31}$. El a remarcat de asemenea că "între Ferigile III, de la Tigveni existã mult mal multe elemente comune eu Canlia decât cu Ferigile I șI II ${ }^{32}$. Este pe deplin firesc ca asemenea afınıtățı să fie expresıa apartenențel ambelor aspecte culturale la etnosul geto-dac șı la civilizața creată de acesta. Dar este la fel de posıbil ca realitățlle cultural - arheologice aduse in discuțle să reflecte și particıparea grupului Ferigıle - Bârsești, în aria sa de divizıune, la constıtuırea aspectului Canlia, care se știe - la vremea sa și pe măsura formăriı și afırmăriı cıvilizațiel geto dace din a doua epocă a fieruluı - a evoluat pe o arle mult extınsă, corespunzând aproape întregului spațlu carpato- dunărean - nord balcanic ${ }^{33}$.

Trebule să admitem că rezolvarea unel probleme ca'cea fonnulată mal sus pretınde un suport documentar consistent. incărcat de argumente numeroase și cât mal sıgure - pentru care descoperirea prezentată de noi nu constitue decât unul dintre elementele de susținere. Apare astfel evidentă necesitatea unor noi descoperiri viltoare sau publicarea tuturor acelora deja efectuate.

Așezărt atribulte grupului cultural Ferigıle-Bârseștı au incepui a fi semnalate în literatura de spectalıtate, in unnă cu mal bıne de două decenii. ¡̆ı 1970. Alexandru Vulpe menționa astfel așezările de la Budeștı, Bârsești-Vâlcea șị 
Orlești, in preajma Drăgășanllor ${ }^{34}$. Tot atunci, Gheorghe I. Petre comunica existența unei așezări Feriglle la Govora-sat, comuna Mihăeștı, jud.Vầlcea ${ }^{35}$. Un an mai târzıu apăreau rezultatele - e adevărat, cu totul modeste- prilejuite de urmărirea in teren a descoperiril fortulte a resturilor de așezare de la Gătejeștili ${ }^{36}$, lar în 1973 se afirma că "au fost surprinse urme de viaṭă din prima epocă a flerulù . de tip Bârsești- Feriglle - la Gherăsenı -Buzăử. In sfârșit, în 1986 erau identıficate și cercetate -concomitent - resturile de așezări Ferigıle de la Sibıciu de Sus, jud. Buzău ${ }^{3 b}$ - o locuință de tip bordel cu contur dreptunghiular , adâncă de $1.40 \mathrm{~m}$ fațā de nivelul antic de cálcare, datată grosso-modo, pe baza materialelor ceramice. in secolul Vl-IV î. Chr. - și locuirea de la Mlăjet - Buzău, prezentată în paginile de față.

Departe de a constitul o documentare satisfăcătoare, deplin concludentă. datele deținute pânả în prezent cu referire la aṣezările grupuluı cultural FerigılleBàrseștı sunt suficiente lotuṣi pentru a atesta caracterul agrar al economiel practıc:ate, modul sedentar de existență și tipul rustic al habitatului ${ }^{39}$, constatate la feṭi situați in zonele dealurilor și depresiuntlor subcarpatice meridionale, intre secolele VII-IV i.Chr.

Adāugând acestea patrimoniului de date și observaṭil rezultate din cercetarea necropolelor, credem că în viltor'se poate adopta, cu indreptățire. conceptul cultura Ferigile-Bârsestu. 
1. Cercetărilé de la Mlăjet - Iunca Topilei au fost efectuate pe bał̌a contractelor nr. $1892 / 1986$ și nr. 1994 (2958)/1987 incheiate de M. N. I. R. cu I. S. P. H. - Bucureștí și au avut ca temă salvarea arheologicả a mărturiilor de culturā materială afectate de amenajările hidrotehnice de pe valea răului Buzãu, in sectoarele Nehoiașu - Pătârlagele și Chirlești - Bãsca Chiajdului. În campania clin 1986, elaborarea planului de săpălură, observațile stralırafice, tratarea complexelor de locuire și intocmirea documentației grafice și foto au fost efectuate in teren de Adrian Bătrâna și Lla Bătrâna, ajưtați temporar de Alexandra Bolomey și Valeriu Leahu. Prelucrarea ceramicii, uneltelor, altor obiecte și redactarea textului la tema de contract au fost făcute atunci de Ija Bătrâna și Valeriu Leahı. İn 1987. colegii Lia și Adrian Bătrâna aflàndu-se pe șantierul Hârșova. toate operațiunile din teren și de laborator, precum și elaborarea textului la studiul de contract au revenit lui Valeriu Leahu, care, ulterior, a redactat și acest text.

2. Alexandra Bolomey, Resturile de animale de la Mlăjet - Lunca Topilei: caracteristici și semnificații, in C. C. E. S. - M. I. R. S. R., Mărturí de cultură materială pe valea râului Buzău in zona amenajărilor hidrotehnice - sectorul Chirlești - Bāsca Chiajdului. Contract nr. 1994 (2958)/1987, p. 46.

3. Ibidem, p. 44 - 54.

4. In cazurile unor recipiente mari, de provizii, începând cu cele din neolitic este neîndoielnic că asemenea orificil aveau rol funcțional, fïnd destinate aerisirii grânelor depozitate.

5. Sebastian Morintz, in Materiale și Cercetäri Arheologice, V. 1958, p. 255 și unn.: VI. 1959. p. 232 și urm.

6. Alexandru Vulpe, Necropola hallststtianã de la Ferigile. Monografie arheologicà (mai departe in text: Ferigile......). 1967, p. 51 - 52, Pl. XI.

7. Idem, in Dacia. N. S., XVI, 1972, p. 84, fig 5/8, 6/5 și îndeosebi 8/2.

8. Idem, op. cit (nota 6), p. 52 - 54, fig 16 și Pl. XII.

9. Idem, Ibidem, p. 44, Pl. IV - V: Dacia, N. S. XXi, 1977, p. 81 - 111 . cu 1l.; XXVI, 1982, p. 77 și urm., cu fig. 7, 15, 17.

10. Idem, op. cit (nota 6), p. 46, Pl. VI.

11 lbidem, p. 38 - 40, fig. 13, Pl. I. II.

12. cfi nota 5 . 
13. Alexandru Vulpe, op. cIt (nota 6), p. 54 și urm, PI. I/6, 13, V/30, XII; pentru aplicațiunea plastică in formă de rhython, analogil la Butucenı și Brăllița (sec. IV - III î. e. n.), cf. Emıll Moscalu, Ceramica traco - detică 1983, Pl. X - XI.

14. Alexandru Vulpe, op. clt. (nota 6), p. 40 - 41, 47 - 49, P1. II, VII.

15. Până in prezent este menționată doar cana cu toartă, lucrată la roată. descoperită într-o necropolă din faza Feriglle III, cercetată la Gătejeștı, jud. Vâlcea; cf. Alexandru Vulpe, Memorla Antiquttatis, II, 1970, p. 132, 190; Gheorghe I. Petre, SCIV. 22, 4, 1971, p. 559. fig. 1/1. Pentru ceramica lucrată là roată descoperită la Bârseșți, cf. Emıl Moscalu, op. cit. p. 183, 209.

16. În $1969 \mathrm{au}_{i}$ fost descoperite la Gătejești - Vâlcea, in apropierea

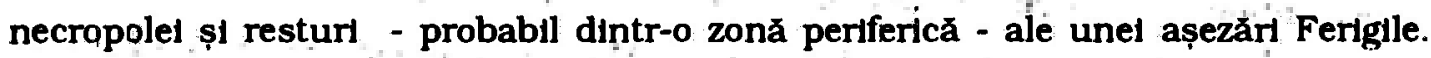
Condițille din teren $\mathrm{n}$-au îngăduit decât o cercetare parțială șı superficłală. $\mathrm{Nu}$ au fost Identıficate locuınțe, filınd dezvelıte șı tratate doar treı gropl menajere. Puținele materlale ceramice - din care au fost reconstitulte un tıp aparte de cană pântecoasă, o strachınă - căzănel și o strachınă cu margınea răsfrântă în interior aparținând fazel Ferigile III, nu sunt însă pe mảsură a ofer criterll nguroase, multıple și sıgure pentru a obține încadrarea culturală și cronologicá a descoperrillor de la Mlăjet - Buzău. Cf. Gheorghe I. Petre, op. ctt. (nota 15), p. 557 $559,561$.

17. Groplle menajere de la Mlăjet - Lunca Topllel nu au oferit, nicl una, materfale suficlente sı caracteristice pentru a putea fi ordonate cronologic. Pe vatră însă au apărut fragmente ceramice Indicând sigur contemporaneitatea cu' bordelul nr. 2.

18. Alexandru Vulpe, op. ct. (nota 6). p. 116. 130 - 131, 132. 152 ș passim.

19. Alexandru Vulpe, Eugenla Popescu, Dacta, N. S., XVI, 1972, p. 75 111: XXVI, 1 - 2, 1982, p. 91-99 cu 11., 111112.

20. Op ct. p. 102. fig. 24 de pa p. 105.

21. C. Buzdugan. Carpica, 1, 1968, p. 83, 92, fig. 5/1 de la p. 85.

22. Emil Moscalu, op. ctt (nota 13), p. 47.

23. Loc. cit și Pl. XVIII, XIX/3,4; A. D. Alexandrescu, Dacta A. S. XXIV, 1980. p. 44 - 45. fig. 15.

24. lbidem, p. 46, fig. 23/15 - 21.

25. Emil Moscalu, op. clt (nota 13), p. 387, Pl. LXI!/10,13. 
26. Alexandru Vulpe, Eugenla Popescu, Dacla, XXVI, p. 112.

27. Emil Moscalu, op. ctt. (nota13), p. 184.

28. Loc. cit.

29. Op. clt. p. 186.

30. Op. cit. p. 185.

31 Op. ctt. p. 186.

32. Op. ctt. p. 184.

33. Op. ctt. p. 189 - 190.

34. Alexandru Vulpe, op. ctt (nota 15), II, p. 132, 190. În acelaș1 context esțe menționată, potrivit informațiel oferite de Victor Teodorescu, și o așezare de tip Ferigile la Budureasca, jud. prahova. Emil Moscalu contestă această incadrare atribuind descoperirea aspectului Canlia (op. cit. (nota 13). p. 186).

35. Cf: Materiale...XI, 1970, p. 466 șı urm.

36. Supra, n. 15 și 16.

37. Gh Diaconu, Studu și cercetär de istorle buzolană 1973, P. 7.

38. C. Buzdugan, G. Trohani, Muzeúl Național de Istorie a Româniel, Cercetăr arheologice. XI. 1992, p. 40 - 41. PI. 6. 7/1

39. Cu referire la tipul de habitat propriu purtătorilor culturil Freigile Bârseștı , Alexandru Vulpe a opinat că "...locuirrle erau de tip răsfirat, cu gospodăril constituite pe famillı mari. izolate unele de altele, poate pe distanțe de kilometri, pe culmile dealurilor orl in zone propice pentru fânețe și un minimum de agricultură. Cf: Academia de Știlnțe Sociale șı Politice a R. S. R., Documente recent descoperite șt informațil arheologice, Bucureșt1. 1985, p. 21 - 22. 
Between 1986-1987 at Mlajet, commune of Neholu, Buzău county, there have been made researches at the remains, of a settlement belonging to the late period of the First Iron Age. 'There have: ben discomered two dwellings, an open air fire plade and ten garbage pits. The dwellings were of earth hut type - the first having an inward flre th place and the second one an qutward fire place, placed very near (plates I,II):

The tultural afid chronological dating of the settlement is proved by the ceramic material (plates iIV, IX) that has various, and very good analggies with Ferigile - Bấrsésti culture. This cultur is characteristic fon the native people, the Getae and is spread on the hills and in the hollows of the southern sub Carpathians. It lasts from the second half of the 7th century B.C. till the end of the 5th - the begining of the 4 th century $\mathrm{B}_{\mathrm{C}} \mathrm{C}$.

Taking into consideration the ceramics found there, there have been differentiated two levels within the late Hallstatian settlement: the first one is represented by the earth hut no ar that belongs to the feriglle III phase and may be dated in the second half of the 5th century thll the beginning of the 4 th century. The second level, represented by the earth - hut no 2 and by the open air fire place may be dated in the second half of the 4th century B.C. more probably by the end of it. Dated in this way, it results that the level foltows after the latest Ferigile type manifestation and belongs to the 5th century B.C. till the beginning of the 4 th one.

It remains as a task for the future, that by adding new discoveries, to be established if the second level of Mlajet belongs to, Ferigile - Bârseștl culture. This thing would come to confirm elther the opinion that Ferigile - Bârseștt type continues its existence on that area thilh this 4 th - 3rd centures B.C. or that this level shows the appartion of another autochtonous culture - the Canlla culture.

159. 
P1. I. Mlăjet - Lunca - Topıllel. Planul șı profilul bordeluluı nr. 1

Pl. II. Mlảjet - Lunca Topılel. Planul șı profilul bordeluluı nr. 2.

Pl. III. Fusalole de lut (1 - 3), ocru roşu (4), fragment de chirpicl cu amprente de schelet lemnos (5). lama unul cuṭt de fler (6). creuzet de platră (7) și râșniță de platră cu frecător (8) descoperite în bordelul nr. 1 .

Pl. IV. Proflle fragmentare de vase lucrate cu mâna descoperite in bordele.

Pl. V. Profle fragmentare de străchıni. Mlăjet -Lunca Topllel.

Pl. VI: Butoni discoldall (1 2,4) șt zoomorf (3) șı vase fragmentare din bordelul nr. 1.

P1. VII. Cești tronconice cu toartă.

Pl.. VII!l. Fragmente ceramice descoperite la Mlăjet - Lunca Topıllel, in bordeiele 1 și 2.

Pl. IX. Fragmente dé vase cu perforațil circulare.

PI. X. Mlăjet - Lunca Topilet. Ceramică hallstattiană din bordeje.

PI. XI. Mlăjet - Lunca Topilel. Fragmente de vase lucrate la roată.

\section{EXPLICATION OF PLATES}

Ist Plate - Mlajet - Lunca Topllet. Plan and profle of hut no 1.

$2^{\text {nd }}$ Plate- Mlăjet - Lunca Topllei. Plan and prônle of hut no 2 ,

$3^{\text {rd }}$ Plate - Clay 'spindle weight ( 1 -3), red ochre (4) fragment of an adobe with imprints of wooden skeleton (5), an Iron knife blade (6), stone melting pot (7) and stone hand mill with rubber (8) - discovered in hut no. 1.

$4^{\text {th }}$ plate - Fragmentary profiles of hand worked vessels discovered in earth huts $5^{\text {th }}$ Plate - Fragmentary profiles of bowls. Mlajet Lunca Topllel $6^{\text {th }}$ Plate - Discoldal and zoomorphous buttons (1-2) and fragments of vessels found in hut no. 1

$7^{\text {th }}$ plate - Troncone-shaped cups witrh handles.

$8^{\text {th }}$ Plate - Pottery fragments discovered at Mlajet - Lunca Topllel in hut 1 and 2. $9^{\text {th }}$ Plate - Fragments of vessels with circular perforations. 
$10^{\text {th }}$ Plate - Mlăjet - Lunca Topilei - Hallstattian pottery found in huts.

$11^{\text {th }}$ Plate - Mlăjet - Lunca Topilel - Fragments of wheel-worked vessels. 

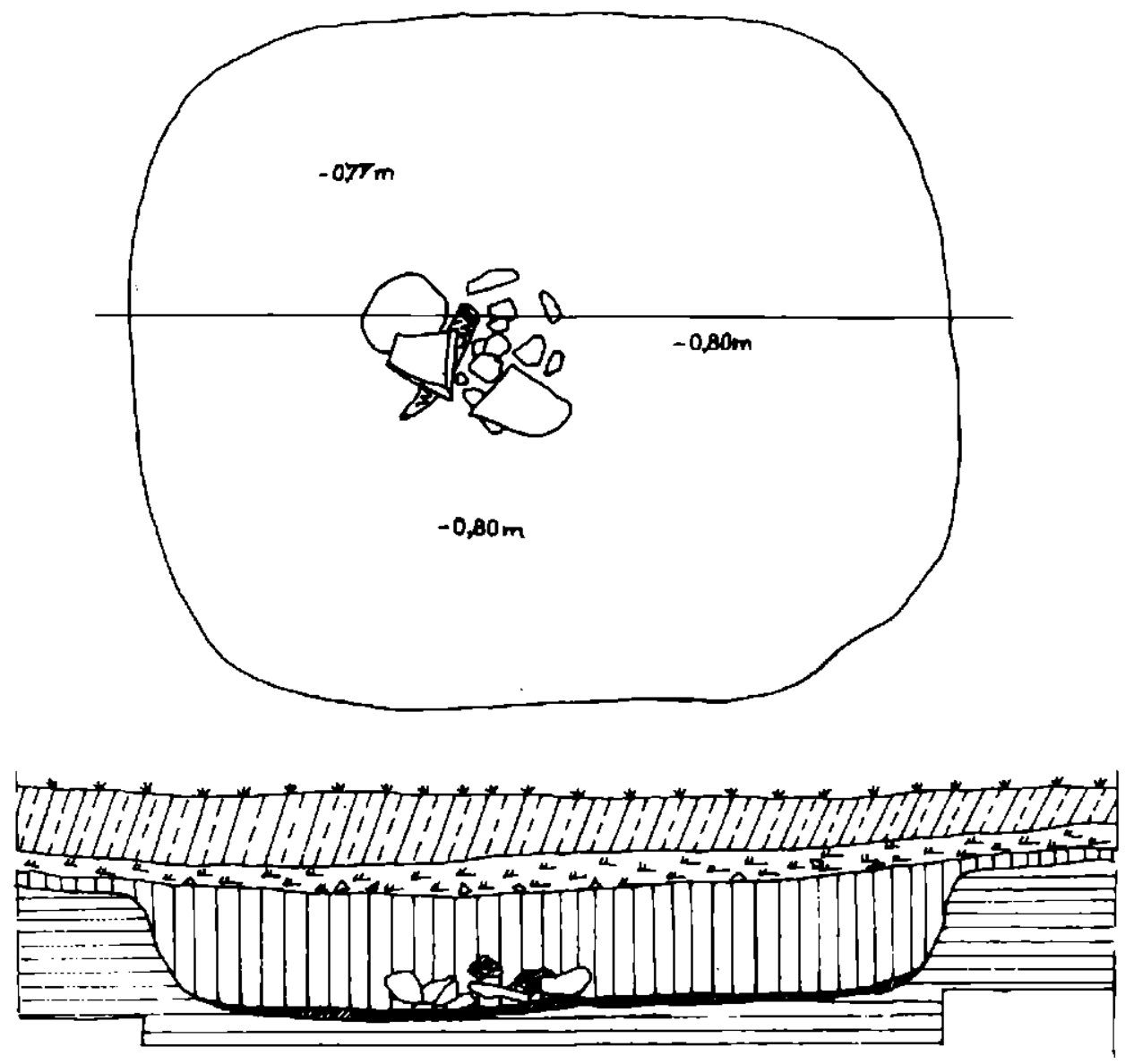

[i]i] Sol vegetal actual

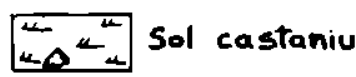

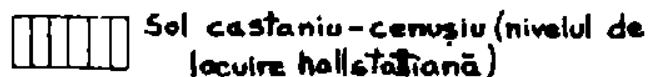
lacuire hallstatrana)

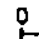
$1 \mathrm{~m}$

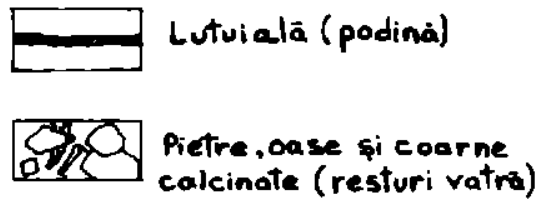

Lut galben (steril)

Planșa I. Mlăjet - Lunca Topilei. Planul și profllul bordeiuluı nr. 1. 

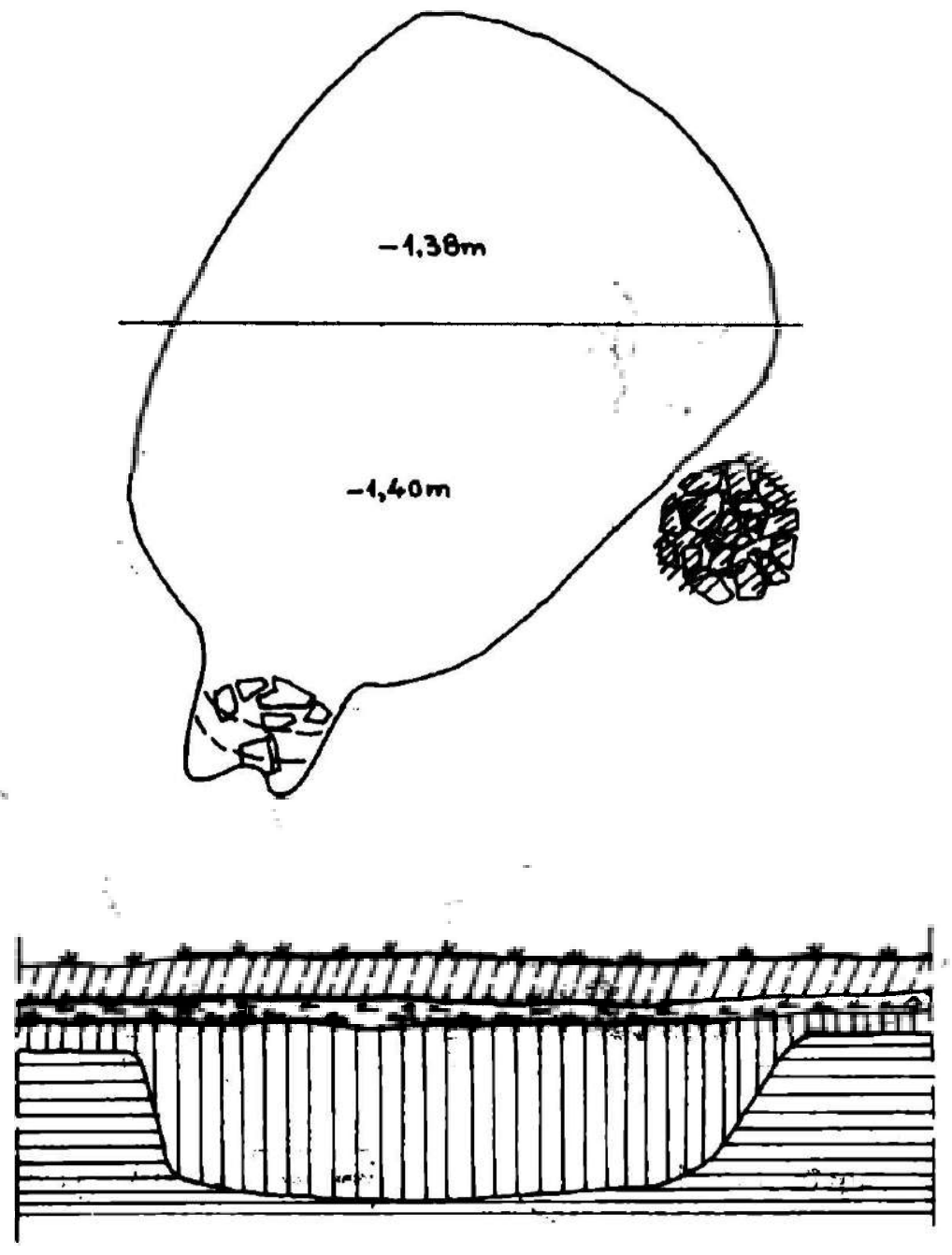

एTiT) Sal vegetal actual,

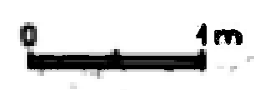

Sol castaniv

IIIII Sol castanlu-cenusiu (nivelul de locuire hallstattanā)

Lut galben (steril)

एक्षी Pietre placind trapte

Nixis Pietre acoperite de lutuialä (vatra)

Planga II. Majet - Lunca Topilet. Plariul al profilul bordetul nr. 2. 

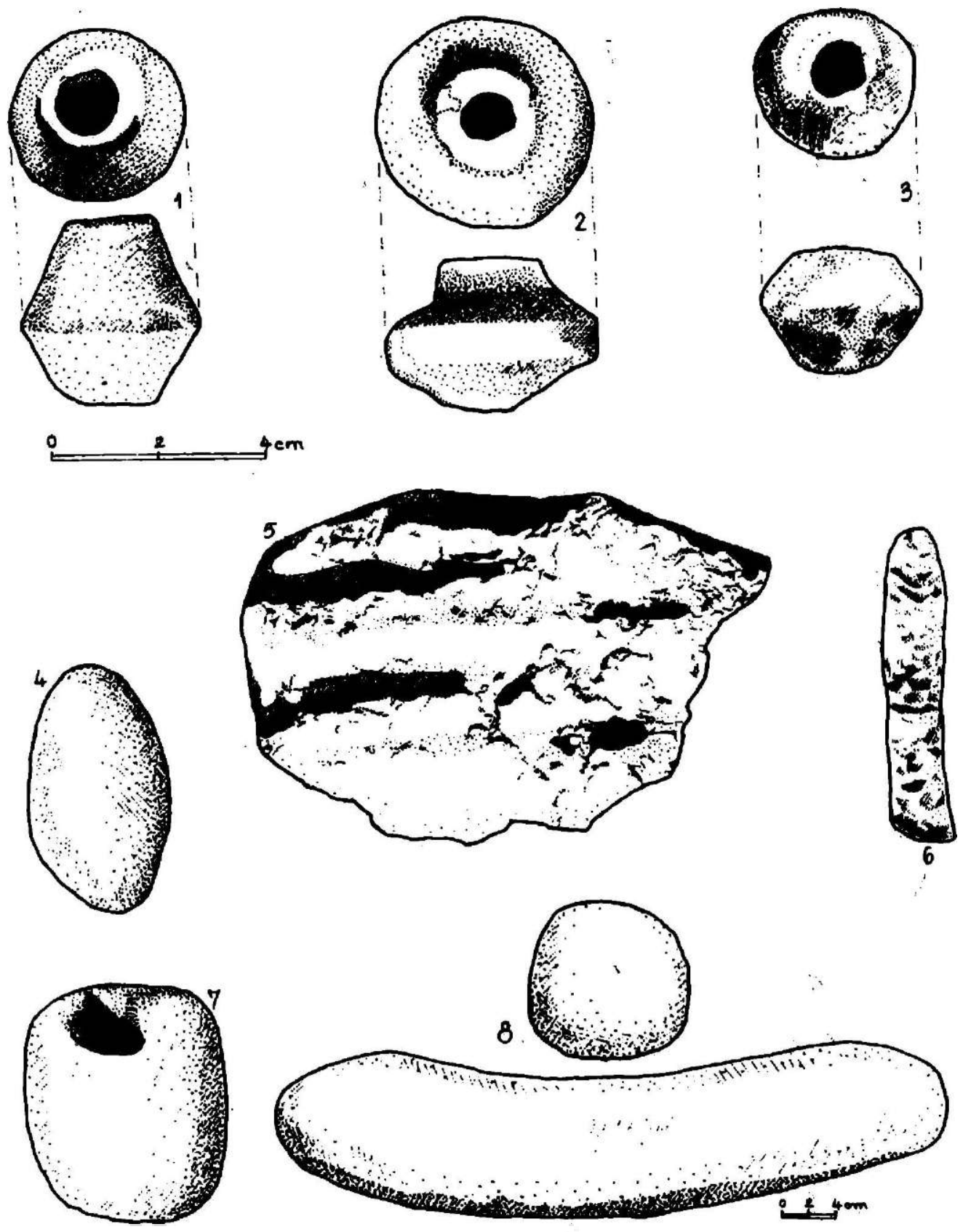

Planșa III. Mlăjet - Lunca Topllet. Fusaiole de lut (1 - 3), ocru roșu (4), fragment de chirpici cu amprente, de schelet lemnos (5), lama unul cuptt de fier (6), creuzet de platră (7) și râșniță de platră cu frecător (8) descoperit în bordelul 1 . 


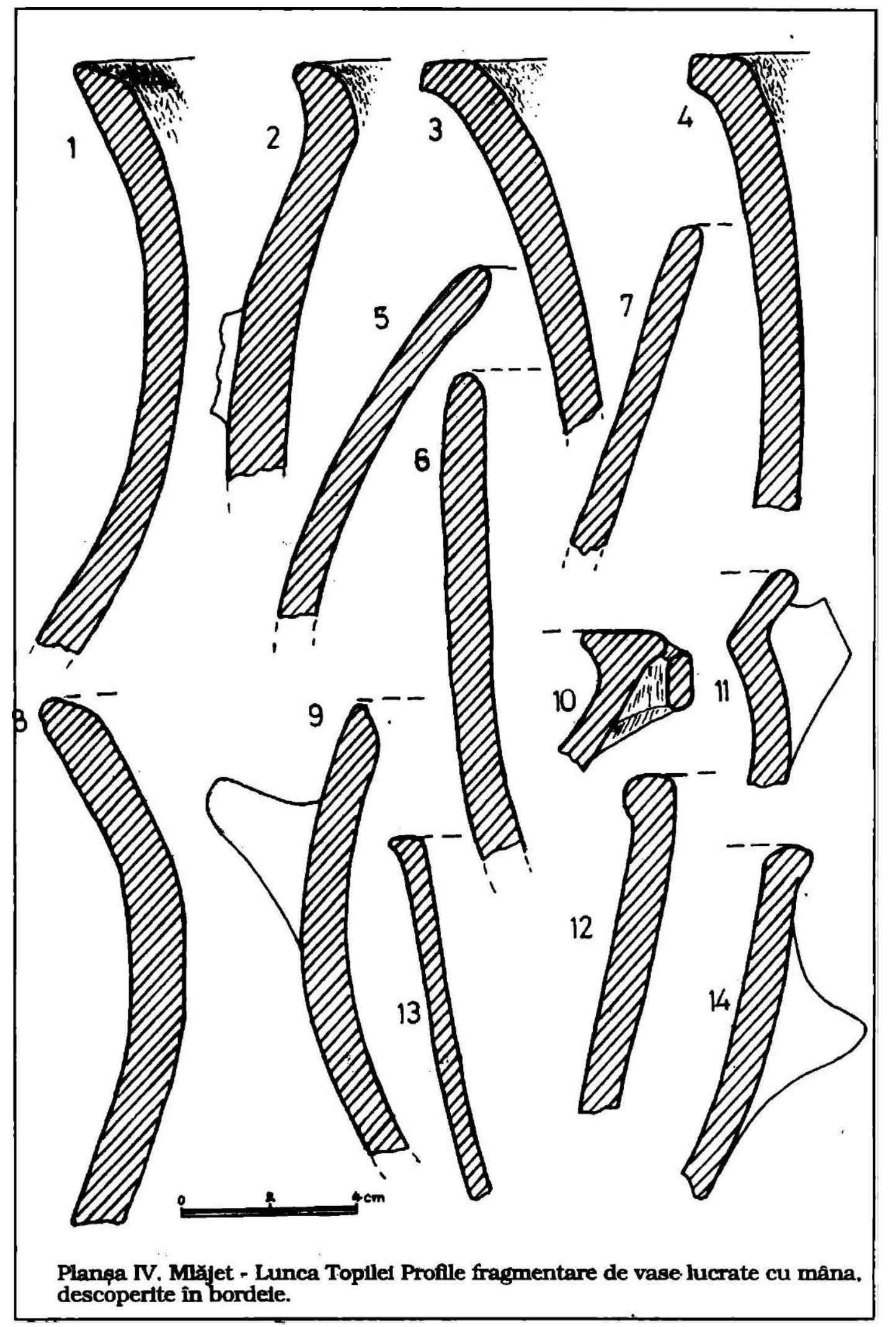




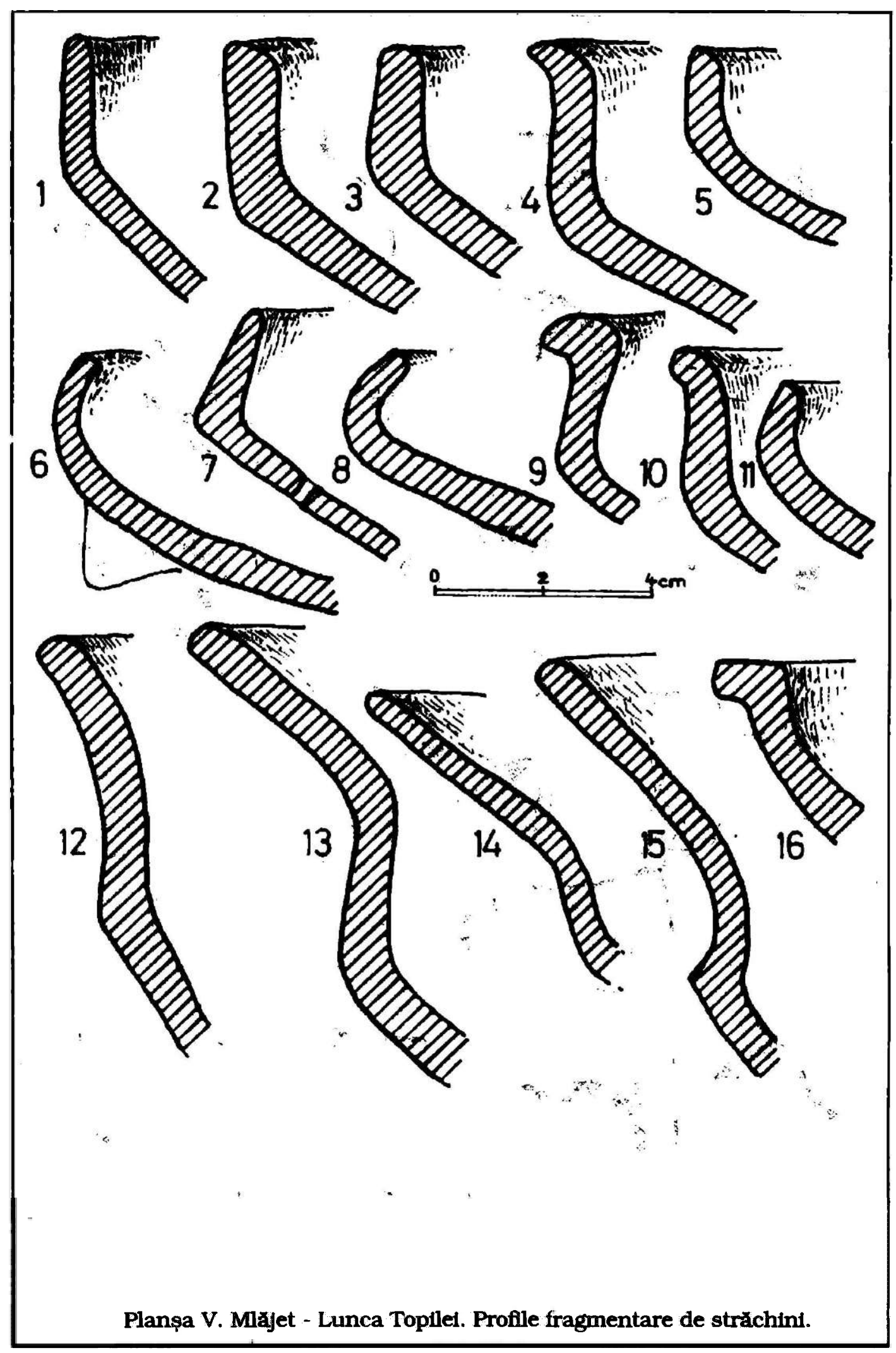




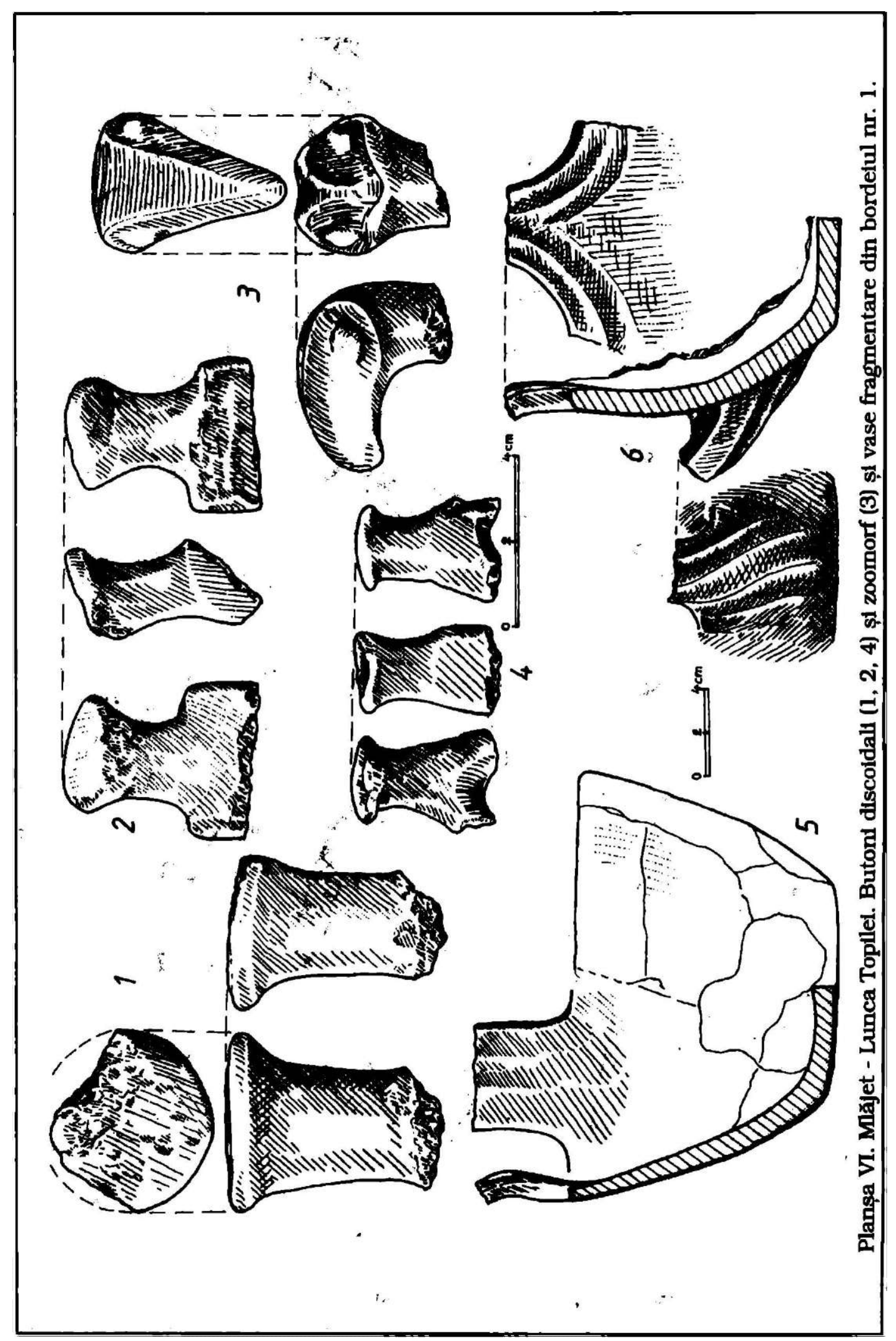




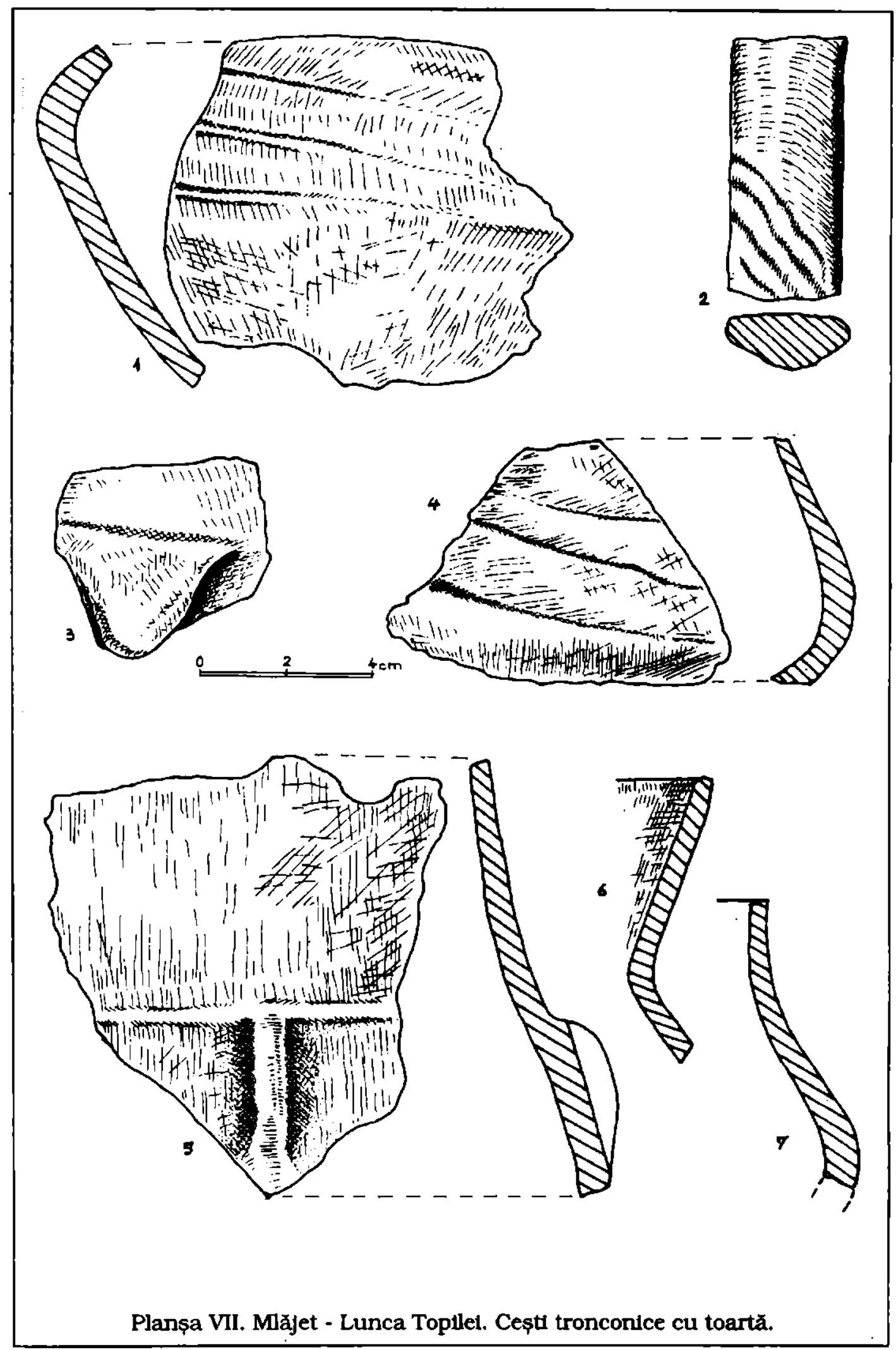




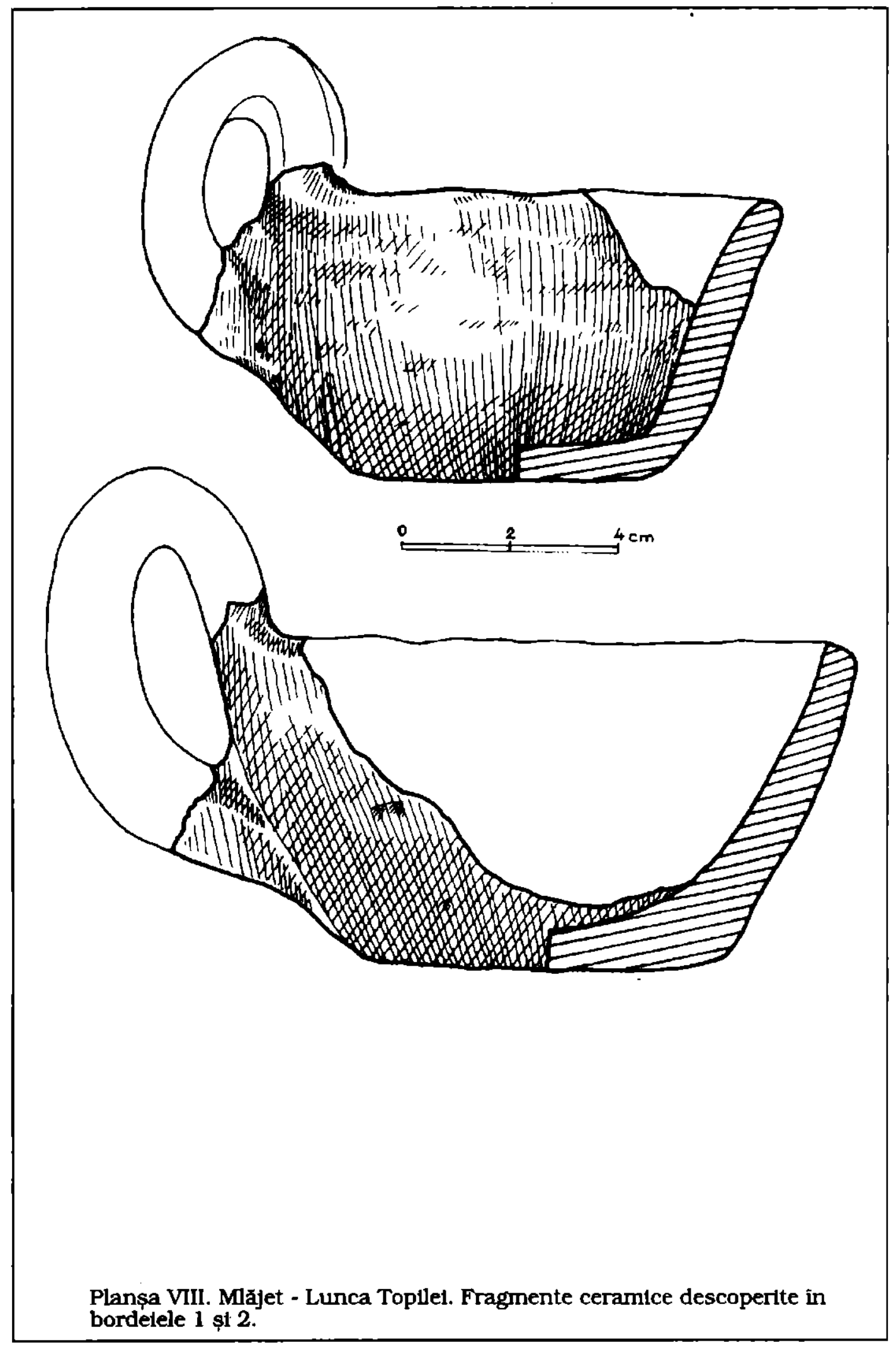




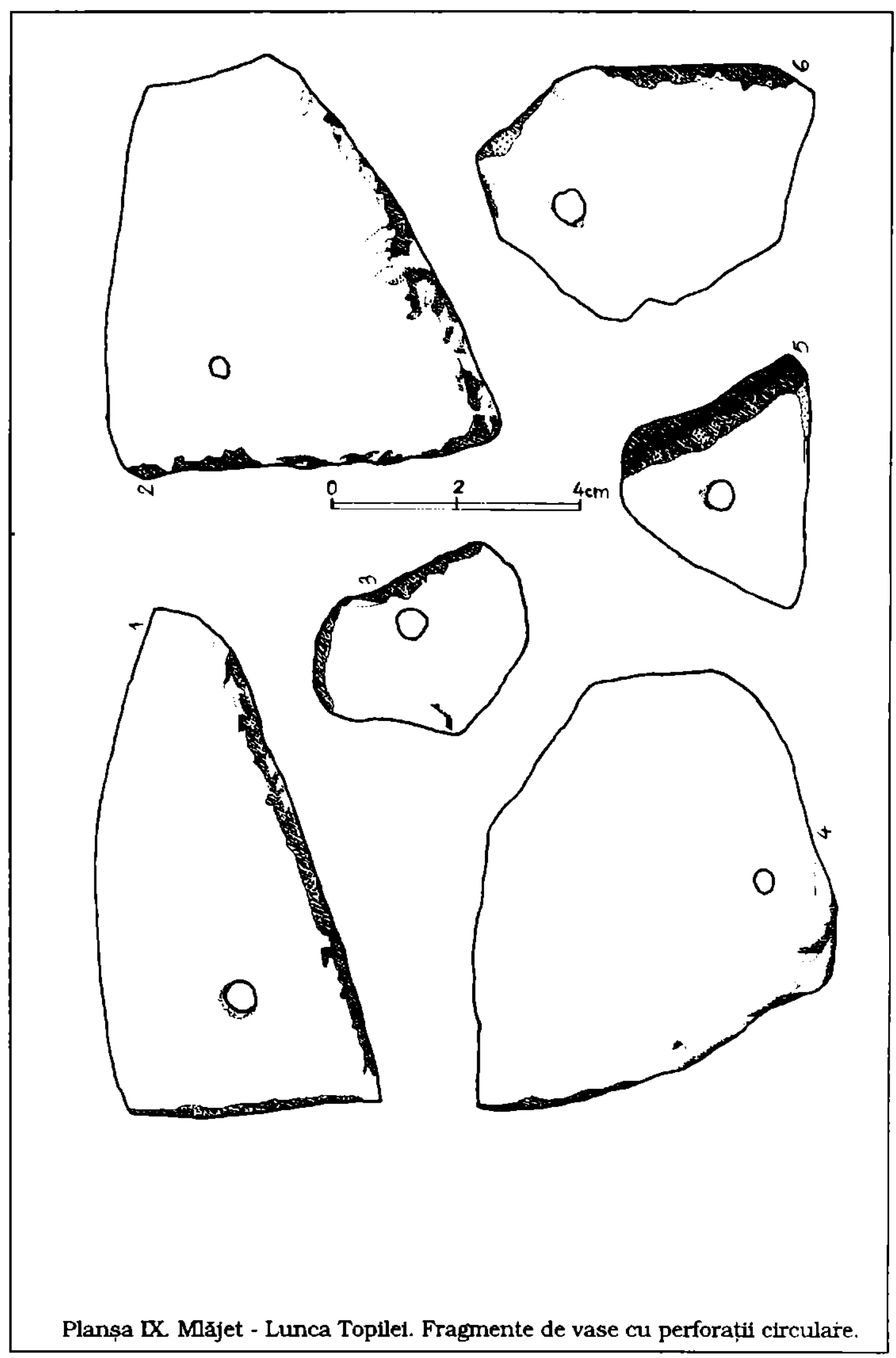



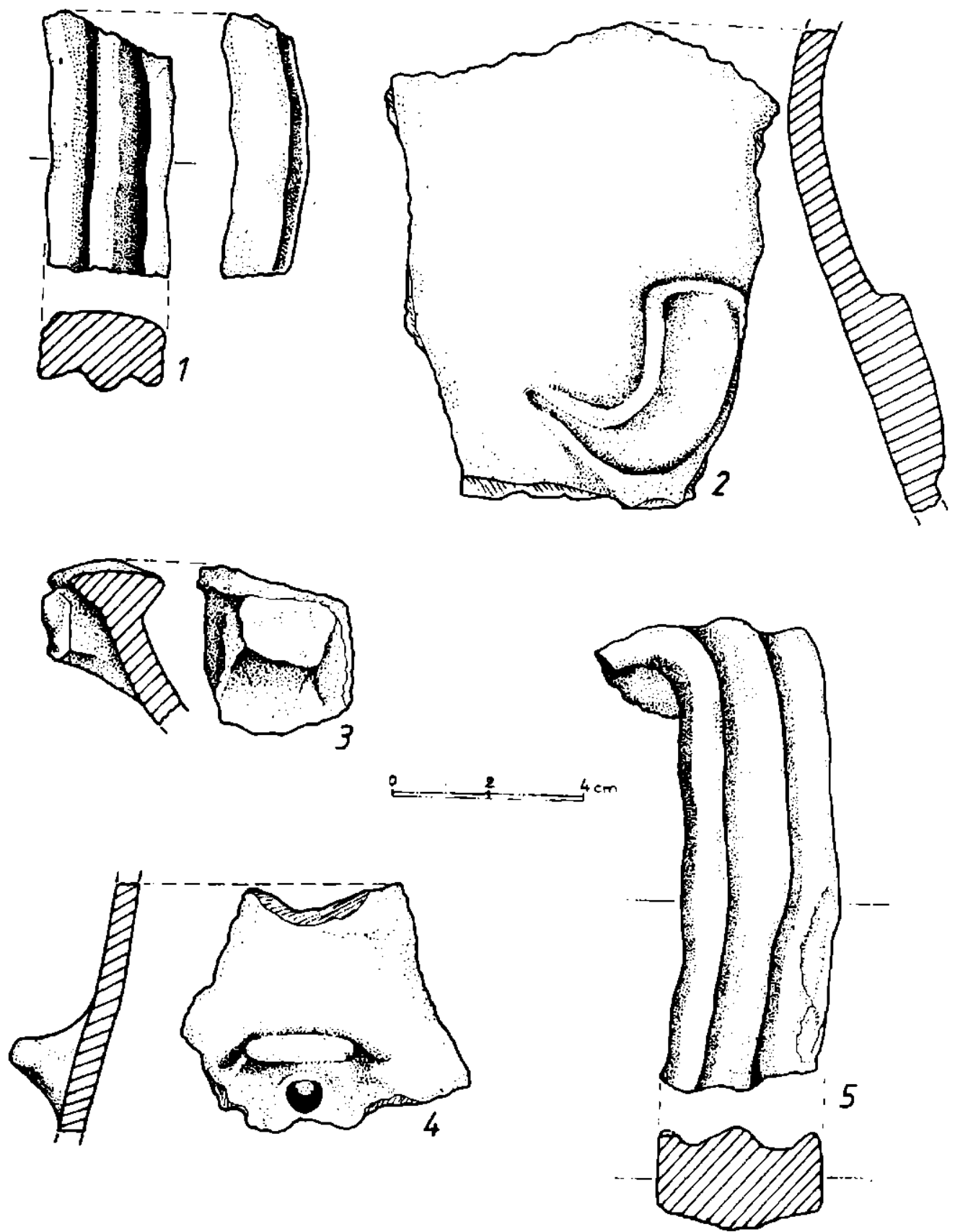

Planșa X Mlăjet - Lunca Topllet. Ceramică hallstattiană din boṛdele. 


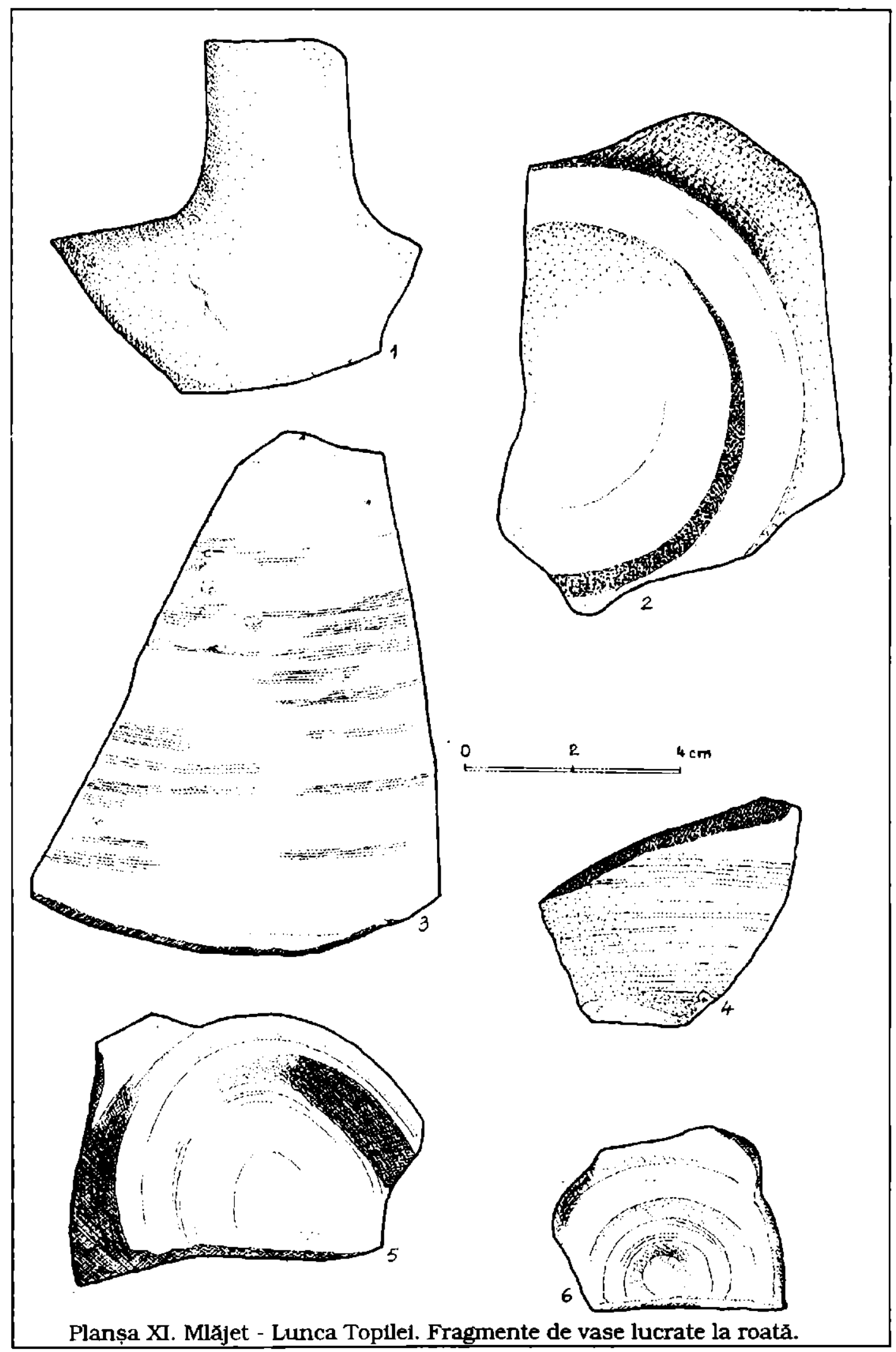

